\title{
THE EFFECT OF IMPURITIES ON THE SURFACE STRUCTURE OF EVAPORATING ICE
}

\author{
By J. D. Cross* \\ (Inland Waters Branch, Department of Energy, Mines and Resources, Ottawa, Ontario, \\ Canada)
}

\begin{abstract}
Micrographs of the surface of evaporating polycrystalline ice containing impurities are presented. The micrographs show that impurities that enter the ice lattice substitutionally enhance the fine structure on the surface, but impurities rejected by the lattice suppress the fine structure. It is concluded that the observed fine structure is not an artifact of the machine but a real property of evaporating ice dependent upon the defects at the surface.

RÉsumé. L'effet des impuretés sur la structure superficielle de la glace en cours d'évaporation. Des micrographies de la surface d'une glace polycristalline contenant des impuretés sont présentées. Les micrographies montrent que les impuretés qui pénètrent dans le réseau cristallin de la glace favorise par compensation une structure déliée en surface, mais que le rejet des impuretés par le réseau cristallin supprime cette structure fine. On conclut que la structure déliée observée n'est pas un artefact de l'appareillage; il s'agit d'une véritable propriété de la surface en cours d'évaporation sous la dépendance des défauts existants en surface.

Zusammenfassung. Der Einfluss von Verschmutzungen auf die Oberflächenstruktur von verdunstendem Eis. Es werden Mikroaufnahmen der Oberfläche von verdunstendem polykristallinem Eis mit Verschmutzungen vorgelegt. Die Mikroaufnahmen zeigen, dass Verschmutzungen, die in das Eisgefüge eindringen, die Feinstruktur auf der Oberfläche wesentlich verstärken, dass dagegen Verschmutzungen, die vom Gefüge abgewiesen werden, die Feinstruktur unterdrücken. Es wird geschlossen, dass die beobachtete Feinstruktur nicht ein künstliches Ergebnis der Apparatur ist; sie ist vielmehr eine spezifische Eigenschaft verdunstenden Eises, die von den Defekten an der Oberfläche abhängt.
\end{abstract}

\section{INTRODUCTION}

Recent studies of polycrystalline ice surfaces with a scanning electron microscope (Odencrantz and others, I968; Cross, $1969[\mathrm{a}],[\mathrm{b}]$ ) have revealed a complex surface structure containing fine filaments less than one micrometre thick. Such surface structure could contribute to the electrification and nucleation processes in clouds (Cross and Speare, 1969; Ruskin, I969). The existence of a highly disordered surface layer with a large concentration of defects has been indicated by deformation studies (Muguruma, 1969), and Jaccard (1967) has reported that evaporation changes the electrical conductivity of ice, probably by producing defects at the surface. Theoretical and experimental studies of ice evaporating in a controlled environment have been carried out by Gukhman and Volynets ( 1968 ) and Novikov and Vagner (1968). These studies deal with the heat and mass transfer conditions for subliming polycrystalline ice in the pressure range $\mathrm{IO}^{-5}$ to $\mathrm{IO}^{5} \mathrm{~N} \mathrm{~m}^{-2}$. The mass loss was found to be mainly controlled by the radiant heat flux to the specimen rather than by conduction and convection. The evaporation was not confined to the geometric surface of the ice but occurred over an extended region, producing a rough surface. These reports support the supposition that the observed structure is a natural structure for pure polycrystalline ice related to the disordered conditions at the surface, and is not an artifact of the microscope. If water containing ionic impurities is frozen, the impurity ions are not generally incorporated into the ice lattice but accumulate at grain boundaries. Ammonium and fluoride ions are an exception. In small concentrations these ions are incorporated substitutionally into the ice lattice and create respectively $\mathrm{D}$ and $\mathrm{L}$ Bjerrum defects. If the surface structure of evaporating polycrystalline ice is not an artifact of the microscope it should be sensitive to the addition of impurities to the water forming the ice and a different behaviour is to be expected in the influence of impurities rejected by the ice and those incorporated in the lattice. This investigation was carried out in order to check the effect of impurities on the surface structure.

* Present address: Department of Electrical Engineering, University of Waterloo, Waterloo, Ontario, Canada. 
EXPERIMENTAL PROGEDURE

All water used in this work was obtained from a commercial still producing water with a resistivity of $6 \mathrm{M} \Omega \mathrm{cm}$. This distilled water will be referred to as pure water. Dilute solutions of the following compounds were made with the pure water: $\mathrm{NH}_{4} \mathrm{OH}, \mathrm{HF}, \mathrm{NH}_{4} \mathrm{Cl}, \mathrm{NaCl}$, and $\mathrm{HCl}$. Polycrystalline ice samples were prepared from the solutions by attaching a droplet (approximately $2 \mathrm{~mm}$ in diameter) to a fine glass fibre mounted on the standard scanning electron microscope specimen stub (Cross and Cross, 1968) and then freezing the droplet at $-50^{\circ} \mathrm{C}$. The ice samples were then examined directly in the microscope without the use of replicas. A frozen droplet in the microscope takes roughly thirty minutes to evaporate to the point at which it falls from the fibre and is lost. Several samples of each type of ice were studied and the micrographs presented here were chosen as being representative of the appearance of each type of ice.
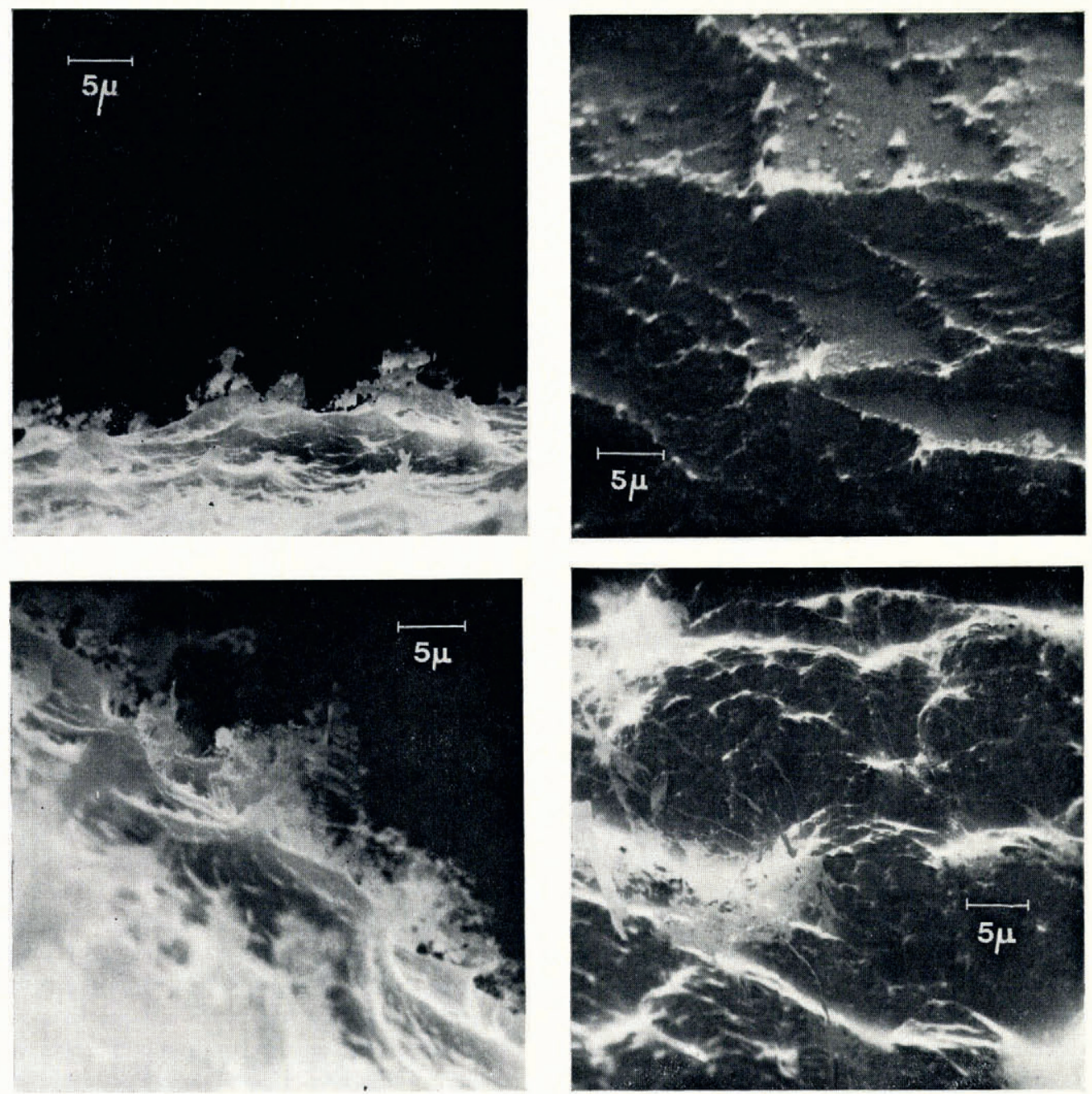

Fig. I (top left). The surface of pure polycrystalline ice, after 10 min evaporation. Instrument magnification $\times 2200$.

Fig. $2 a$ (top right). $\mathrm{NH}_{4} \mathrm{OH}$ doped ice, immediately after insertion in the microscope. Instrument magnification $\times 2700$.

Fig. $2 b$ (bottom left). $\mathrm{NH}_{4} \mathrm{OH}$ doped ice, after 10 min evaporation. Instrument magnification $\times 2600$.

Fig. $2 \mathrm{c}$ (bottom right). $\mathrm{NH}_{4} \mathrm{OH}$ doped ice, after ${ }_{5} 5 \mathrm{~min}$ evaporation. Instrument magnification $\times 2600$. 
Results

A typical micrograph of pure ice after ten minutes in the microscope is shown in Figure $\mathrm{I}$. The surface has the fine structure reported previously. Figure 2 shows three micrographs typical of dilute solutions of $\mathrm{NH}_{4} \mathrm{OH}$. Concentrations of Io parts per million and Ioo parts per million were studied and no significant difference was seen between them. Soon after insertion in the microscope the surface had crystalline features as shown in Figure 2a. As evaporation proceeded the complex structures shown in Figure $2 \mathrm{~b}$ and $\mathrm{c}$ developed.

Dilute solutions of $\mathrm{HF}$ behaved somewhat similarly, to the $\mathrm{NH}_{4} \mathrm{OH}$ solutions. Initially the surface had a marked crystalline appearance as in Figure $3 \mathrm{a}$ and as the evaporation
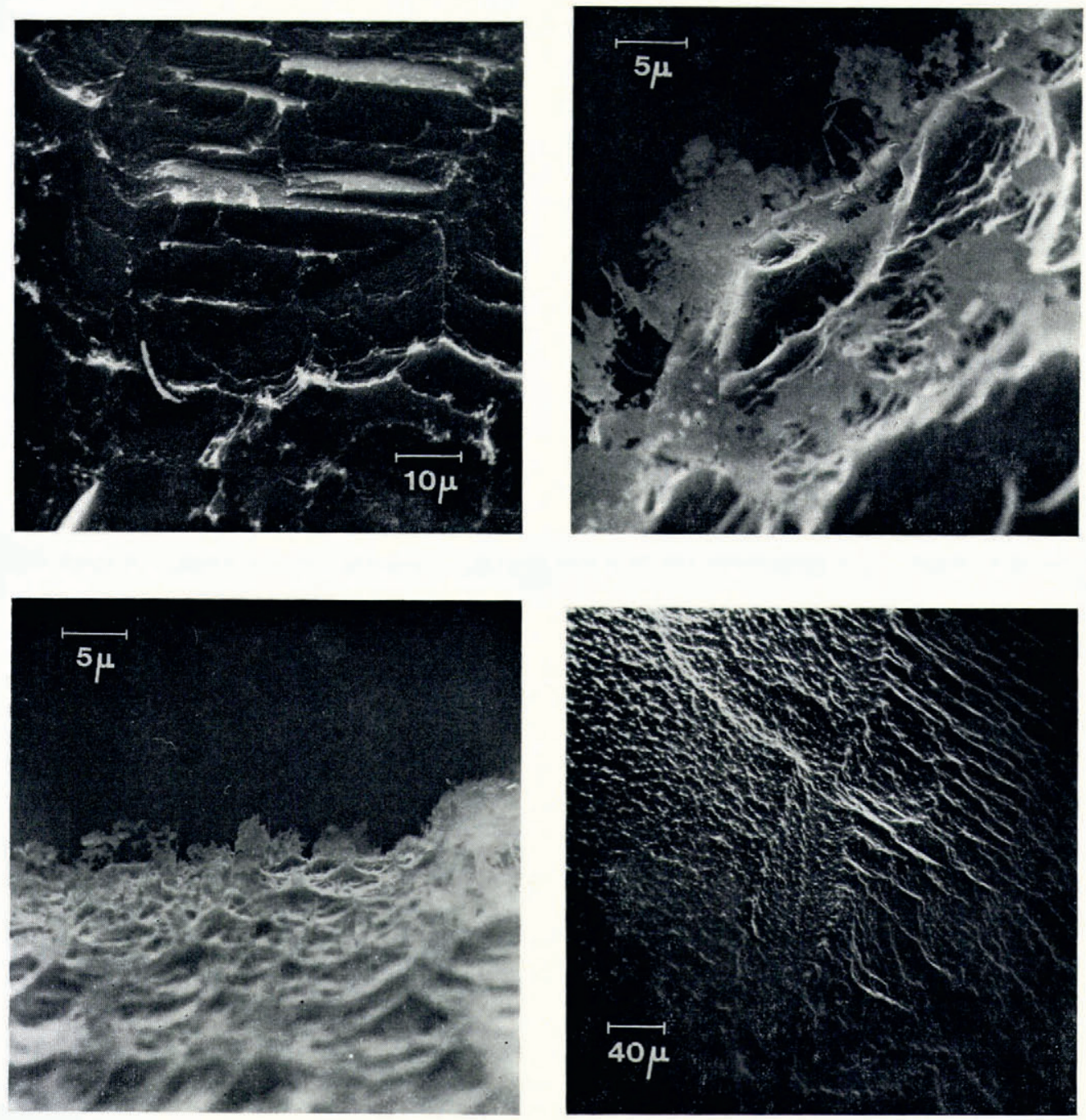

Fig. $3^{a}$ (top left). HF doped ice, immediately after insertion in the microscope. Instrument magnification $\times 700$.

Fig. $3^{b}$ (top right). HF doped ice, 1o p.p.m. after 10 min evaporation. Instrument magnification $\times 2300$.

Fig. 3c (bottom left). HF doped ice, Ioo p.p.m. after Io min evaporation. Instrument magnification $\times 2300$.

Fig. $4^{a}$ (bottom right). $\mathrm{NH}_{4} \mathrm{Cl}$ doped ice, immediately after insertion in the microscope. Instrument magnification $\times 250$. 
proceeded a complex surface structure developed but the structure varied with the concentration of HF. With a concentration of to parts per million the appearance was almost indistinguishable from the $\mathrm{NH}_{4} \mathrm{OH}$ solutions, as shown in Figure $3 \mathrm{~b}$. With roo parts per million of $\mathrm{HF}$ the surface structure was lower and less delicate as shown in Figure $3 \mathrm{c}$.

Ice made from dilute solutions of $\mathrm{NH}_{4} \mathrm{Cl}$ is initially crystalline in appearance as in Figure $4 \mathrm{a}$ and evaporation reveals an extremely complex surface structure as in Figure $4 \mathrm{~b}$ and c. Increasing the concentration of $\mathrm{NH}_{4} \mathrm{Cl}$ from Io parts per million to Ioo parts per million produced a slightly more compact surface structure as in Figure $4 \mathrm{c}$.
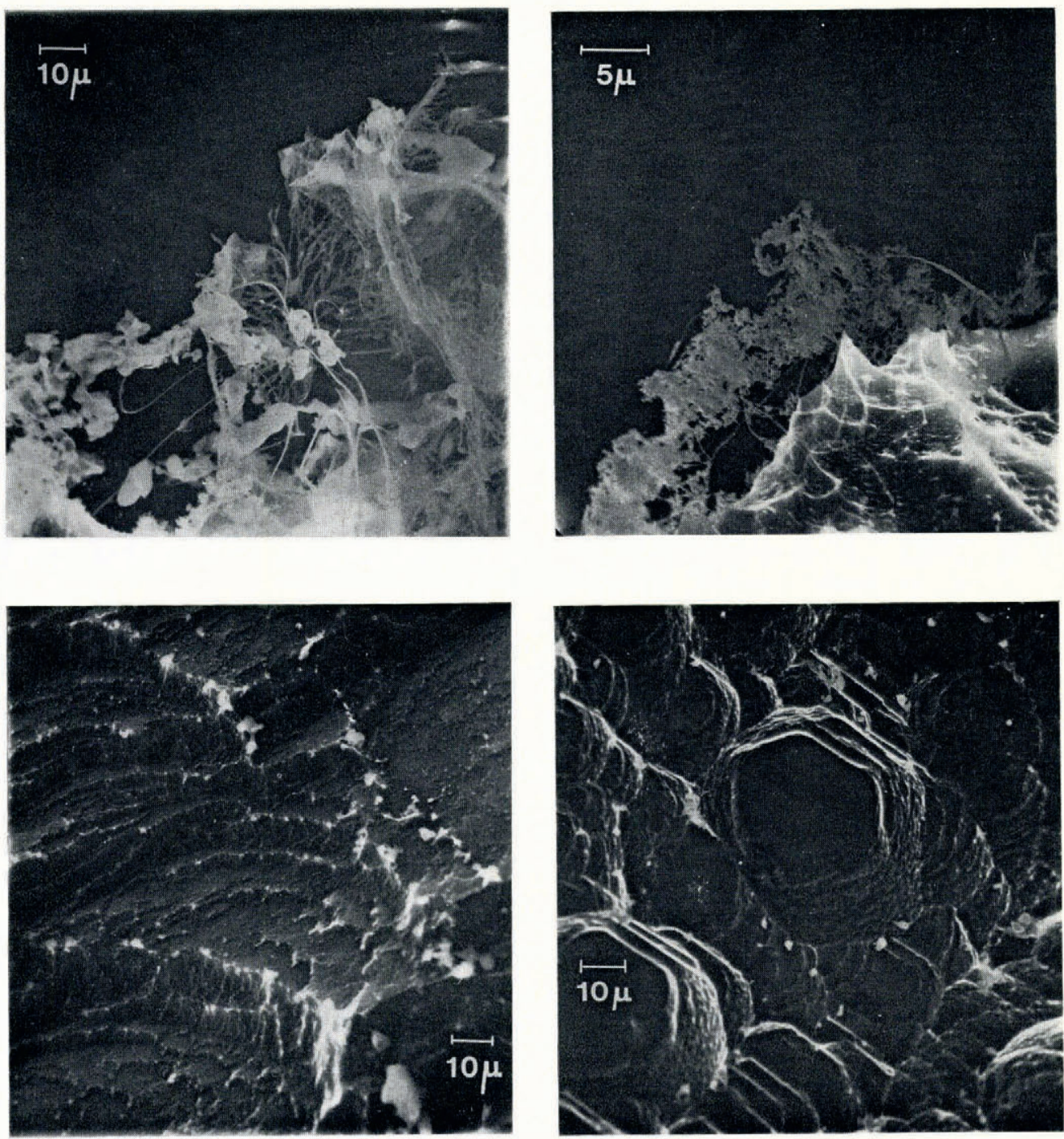

Fig. $4 b$ (top left). $\mathrm{NH}_{4} \mathrm{Cl}$ doped ice, Io p.p.m. after ${ }_{15}$ min evaporation. Instrument magnification $\times I_{2} 200$. Fig. $4 c$ (top right). $\mathrm{NH}_{4} \mathrm{Cl}$ doped ice, roo p.p.m. after 15 min evaporation. Instrument magnification $\times 2500$.

Fig. 5 a (bottom left). HCl doped ice 4 p.p.m. after 15 min evaporation. Instrument magnification $\times I 300$.

Fig. 5 b (bottom right). HCl doped ice to p.p.m. after Io min evaporation. Instrument magnification $\times 880$. 
Ice doped with 4 parts per million and 40 parts per million of $\mathrm{HCl}$ was examined and all specimens had a crystalline appearance as shown in Figure $5 \mathrm{a}$ and b. No fibrous surface structures were seen on any of the $\mathrm{HCl}$ doped samples. A similar result was obtained with ice containing io parts per million of $\mathrm{NaCl}$. A crystalline appearance as shown in Figure $6 \mathrm{a}$ was typical of this ice and in some cases at grain boundaries small spheroids of what appeared to be rejected impurities could be seen as in Figure $6 \mathrm{~b}$.
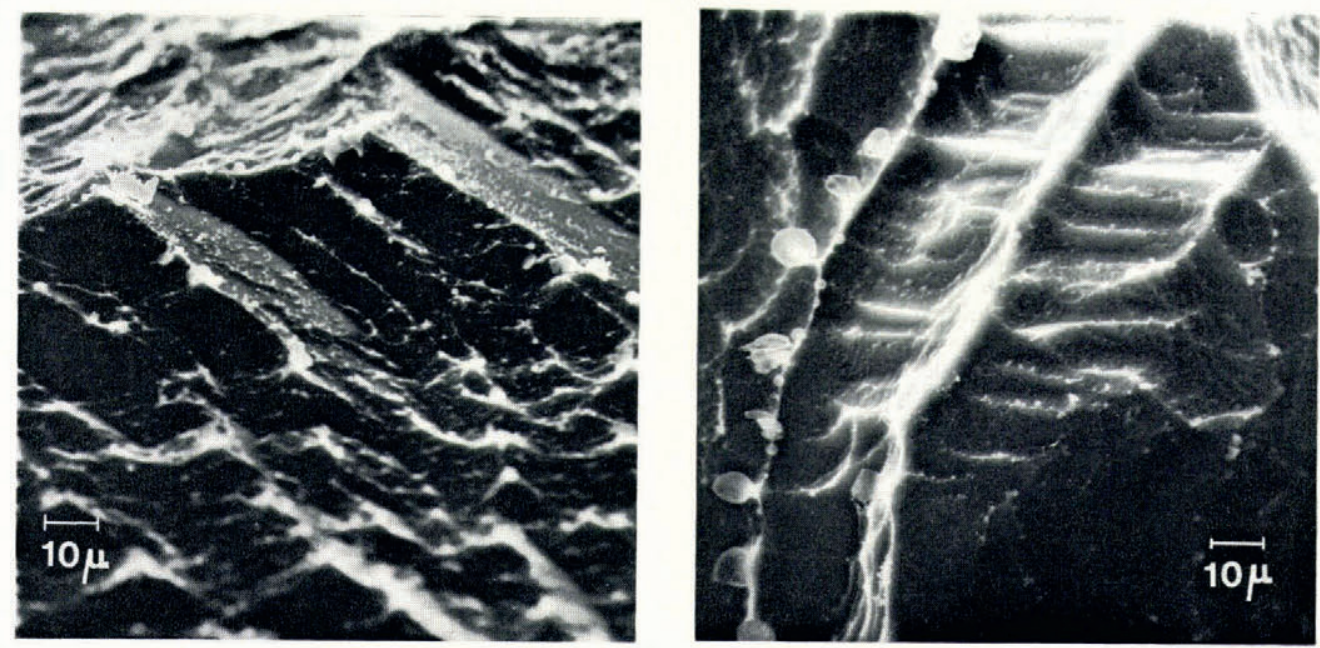

Fig. $6 a$ (left). . NaCl doped ice ro p.p.m. after Io min evaporation. Instrument magnification $\times$ I 300 .

Fig. $6 b$ (right). $\mathrm{NaCl}$ doped ice Io p.p.m. after Io min evaporation. Instrument magnification $\times 880$.

\section{Discussion}

The micrographs show clearly that the presence of small quantities of impurities modifies the surface structure. Impurities that can be incorporated into the lattice enhance the surface structure as shown in Figures 2, 3 and 4. Impurities that are rejected by the ice suppress the fibrous surface completely structure. Ammonium ions and fluoride ions are only incorporated in the lattice in small quantities, therefore when water containing $\mathrm{roo}$ parts per million of $\mathrm{NH}_{4} \mathrm{OH}, \mathrm{HF}$ or $\mathrm{NH}_{4} \mathrm{Cl}$ is frozen some of these impurities are rejected and accumulate at the grain boundaries. In the case of $\mathrm{NH}_{4} \mathrm{OH}$ the impurity is more volatile than the ice, and during evaporation the concentration of impurity at grain boundaries will remain small. In the case of $\mathrm{HF}$ and $\mathrm{NH}_{4} \mathrm{Cl}$ evaporation will result in an accumulation of impurities and the surface structure in these cases is less prominent. In the case of $\mathrm{NaCl}$ and $\mathrm{HCl}$ doping, the impurities are rejected and no surface structure develops. The conclusion to be drawn from these results is that the fibrous surface structure observed on evaporating polycrystalline ice is in some way a result of the large number of defects present and it is through the extra defects introduced by the ions that enter the lattice substitutionally that these ions enhance the complex surface structure. The fine structure cannot be attributed to an artifact of the microscope and it is possible that such a structure may exist in ice evaporating naturally.

\section{Acknowledgements}

The author wishes to thank Dr T. Nakaruma of the Department of Energy, Mines and Resources for providing the solutions used in this work and the Department of Agriculture for use of the scanning electron microscope.

MS. received 13 May 1970 


\section{REFERENCES}

Cross, J. D. I969[a]. Scanning electron microscopy of evaporating ice. Science, Vol. I64, No. 3876, p. 174-75.

Cross, J. D. $1969[\mathrm{~b}]$. Study of the surface of ice with a scanning electron microscope. (In Riehl, N., and others, ed. Physics of ice: proceedings of the international symposium on physics of ice, Munich, Germany, September 9-14, 1968. Edited by N. Riehl, B. Bullemer, H. Engelhardt. New York, Plenum Press, p. 81 -94.)

Cross, J. D., and Cross, P. M. 1968. Scanning electron microscopy of materials containing water. Fournal of Scientific Instruments (Journal of Physics, E), Ser. 2, Vol. 1, No. 10, p. I 1 23-24.

Cross, J. D., and Speare, P. A. I969. Electrical aspects of the evaporation of ice. British Journal of Applied Physics (Fournal of Physics, D), Ser. 2, Vol. 2, No. 7, p. $1021-25$.

Gukhman, A. A., and Volynets, A. Z. 1968. O kharaktere sublimatsii l'da v vakuume [Nature of ice sublimation in vacuo]. Inzhenerno-Fizicheskiy Zhurnal, Tom ${ }_{15}$, No. 5, p. 777-81.

Jaccard, C. I967. Electrical conductivity of the surface layer of ice. (In Ōura, H., ed. Physics of snow and ice: international conference on low temperature science. . . . 1966. . . Proceedings, Vol. I, Pt. I. [Sapporo], Institute of Low Temperature Science, Hokkaido University, p. 173-79.)

Muguruma, J. 1969. Influence of the surface layer on the plastic deformation of ice single crystals. (In Riehl, N., and others, ed. Physics of ice: proceedings of the international symposium on physics of ice, Munich, Germany, September 9-14, 1968. Edited by $\mathcal{N}$. Riehl, B. Bullemer, H. Engelhardt. New York, Plenum Press, p. 2 I $3{ }^{-16}$.)

Novikov, P. A., and Vagner, Ye. A. I 968. Issledovaniye mekhanizma teplo- i massoobmena pri sublimatsii l'da v vakuume [Heat and mass transfer mechanism during ice sublimation in vacuo]. Inzhenerno-Fizicheskiy Zhurnal, Tom 15 , No. 5, p. 788-93.

Odencrantz, F. K., and others. r968. Mechanism for multiplication of atmospheric ice crystals: apparent charge distribution on laboratory crystals, by F. K. Odencrantz, W. S. McEwan, P. St. Amand, W. G. Finnegan. Science, Vol. 16o, No. 3834 , p. 1345-46.

Ruskin, R. E. 1969. Multiplication of ice embryos by ice-whisker sheddings. Science, Vol, r66, No. 3907 , p. 906. 